DOI: http://doi.org/10.4038/jepsl.v8i1.7875

\title{
Assessment of Soil Erosion in Uma Oya Catchment, Sri Lanka
}

\author{
B.A.R.H. Dias ${ }^{1}$, E.P.N. Udayakumara ${ }^{2, \#}$, J.M.C.K. Jayawardana ${ }^{3}$, \\ S. Malavipathirana ${ }^{4}$ and D.A.T.W.K. Dissanayake ${ }^{5}$ \\ 1,2 and 3 Department of Natural Resources, Faculty of Applied Sciences, \\ Sabaragamuwa University of Sri Lanka, Belihuloya, SRI LANKA. \\ ${ }^{4}$ Department of Physical Sciences and Technology, Faculty of Applied Sciences, \\ Sabaragamuwa University of Sri Lanka, Belihuloya, SRI LANKA. \\ ${ }^{5}$ Residue Analysis Laboratory, Industrial Technology Institute, Bauddhaloka \\ Mawatha, Colombo 07, SRI LANKA. \\ \#Corresponding Author: \\ Tele: (94) 718569440;E-mail: udayaepn@gmail.com
}

\begin{abstract}
Soil erosion is one of the major threats which affects farm productivity and water quality in river catchments. Quantification of human-induced soil loss is an imperative measure in catchment management. Among the catchments in Sri Lanka, the highest sediment yield has been reported from the Upper Uma Oya catchment (UOC) which is a sub-catchment of the Upper Mahaweli catchment. The Mahaweli watershed is the most important watershed in Sri Lanka since the size and the economic importance of it. Hence, this study was conducted considering the ten selected sub-watersheds of Uma Oya Watershed (UOW) in Sri Lanka to quantify soil erosion. Soil erosion of UOW was calculated using Integrated Valuation of Ecosystem Services and Tradeoffs (InVEST) Sediment Delivery Ratio (SDR) model. It was found that the current soil erosion rates in the watershed is varied between 14.0-648.6 t/ha/yr. Results of the study disclose that the soil erosion rates of UOW are 3 to 130 times faster than the soil loss tolerance in Sri Lanka. Findings of the study suggest that the implementation of sustainable watershed management options are crucial in order to reduce soil erosion and to enhance the quality of the watershed.
\end{abstract}

Key words: Catchment management, Farm productivity, InVEST SDR model, Soil erosion 


\section{Introduction}

Watersheds are important in supplying precious water resource for humans and for ecosystem functions (Alam et al. 2006; Jayawardana et al. 2016) but are significantly affected by human induced soil erosion (Al-Kaisi et al. 2009). Soil erosion is among the greatest harmful worldwide environmental concerns since it causes detrimental effects on both on-site and off-site. Soil erosion is a process of soil loosening, transport and deposition. This process generally results in relocating the top soil that is rich in nutrients, organics and life of soil elsewhere on-site or is transported offsite where the eroded matter accumulates in drainage channels and this occurs severely on poorly managed sloppy areas (Issaka and Ashraf 2017; Shi et al. 2012). Therefore, soil erosion is closely linked with the reduction in farm productivity and pollution in nearby wetlands and water bodies (Issaka and Ashraf 2017).

Soil erosion is caused by natural agents and anthropogenic activities and it is basically occurred due to water and wind (Issaka and Ashraf 2017). Agricultural practices, clearance of natural forest cover, surface mining, urbanization and construction activities are causative land use practices that accelerate the natural soil erosion rates (Cheng et al. 2017; Diyabalanage et al. 2017; Pimentel 1993). The main reason for the accelerated soil erosion is enhancing pressure on fragile ecosystems and lands due to the rapid growth of population (Diyabalanage et al. 2017; Lal 2003). The resultant impacts of soil erosion include water quality degradation in watersheds, (Al-Kaisi et al. 2009) increasing siltation in the inland reservoirs, decreasing soil fertility on arable lands (Diyabalanage et al. 2017; Lal 2003; Pimentel 1993) and increasing the risk of low land flash flooding (Al-Wadaey and Ziadat, 2014; Issaka and Ashraf 2017). Severe soil erosion that results in excessive silt export to waters or reservoirs causing disturbances on aquatic life as well as reduced quality of the eco systems (Issaka and Ashraf 2017).

The region of South Asia is severely facing to the problem of soil erosion by water and wind (Lal 2001; Singh et al. 1992; Venkateswarlu 1994). Soil erosion results in serious financial losses in countries whose economies are depend on workability and efficiency of soils (Mengstie 2009) and Sri Lanka is one of the South Asian tropical countries whose economy is mainly depending on agriculture. The highest sediment yield of it is reported from the Upper UOW which is a sub-watershed of the Upper Mahaweli watershed (Diyabalanage et al. 2017; Hewawasam and Illangasinghe 2015). The Mahaweli watershed is the most important watershed in Sri Lanka since the size and the economic importance of it (Diyabalanage et al. 2017; Gunathilake and Vieth 2000; Hewavisenthi 1997).

It is the largest watershed in Sri Lanka and provides water to significant multipurpose reservoirs in the country (Hewawasam 2010; Jayawardana et al. 2017). In 
the Upper Mahaweli catchment (UMC), a considerable land cover changes have occurred due to anthropogenic influences during the last few decades. Most of the areas covered with natural forest cover have been cleared for urban settlements and agriculture.

Evaluation of soil erosion which is an impact on the quality of watersheds is important in order to take corrective decisions in catchment management planning. With the increment of anthropogenic influences on UOW, assessing and having updated measures on soil erosion are essential. Therefore, the present study was conducted in the UOW which is a sub-watershed of Upper Mahaweli watershed in Sri Lanka with the aim of assessing the soil erosion rates.

\section{Materials and Methods}

\section{Study Area}

The UOW is a sub-watershed of the Upper Mahaweli watershed which covers $15 \%$ of the land in the country (Hewawasam 2010). It originates from Piduruthalagala at an elevation of about $2500 \mathrm{~m}$, flows eastwards, changes its course northwards beyond the Welimada plateau and joins the Mahaweli River discharging into the Rantambe reservoir at an elevation of $152 \mathrm{~m}$ (Rathnayake 2016). The Uma Oya catchment covers about $765 \mathrm{~km}^{2}$ with a mean slope gradient of $5^{\circ}$ to $30^{\circ}$ (Hewawasam 2010). It receives an annual rainfall from $1100 \mathrm{~mm}$ to $1400 \mathrm{~mm}$ and the temperature ranges between 15 and $27^{\circ} \mathrm{C}$ (Jayawardana 2016). The dominant soil type present in this area is ultisol (Jayawardana 2016; Panabokke 1996). Paddy cultivation is predominant in the rainy season and the vegetable cultivation is predominant during the dry season in the study area. While paddy is the predominant cultivation in the rainy season, vegetable crops proliferate the area during the dry season in the study area.

Ten sub-watersheds draining into the Uma Oya River were selected as the sampling locations (Figure 1). The selected sub-watersheds ranged from undisturbed forests to landscapes extensively altered by agriculture, urban settlements and deforestation. 


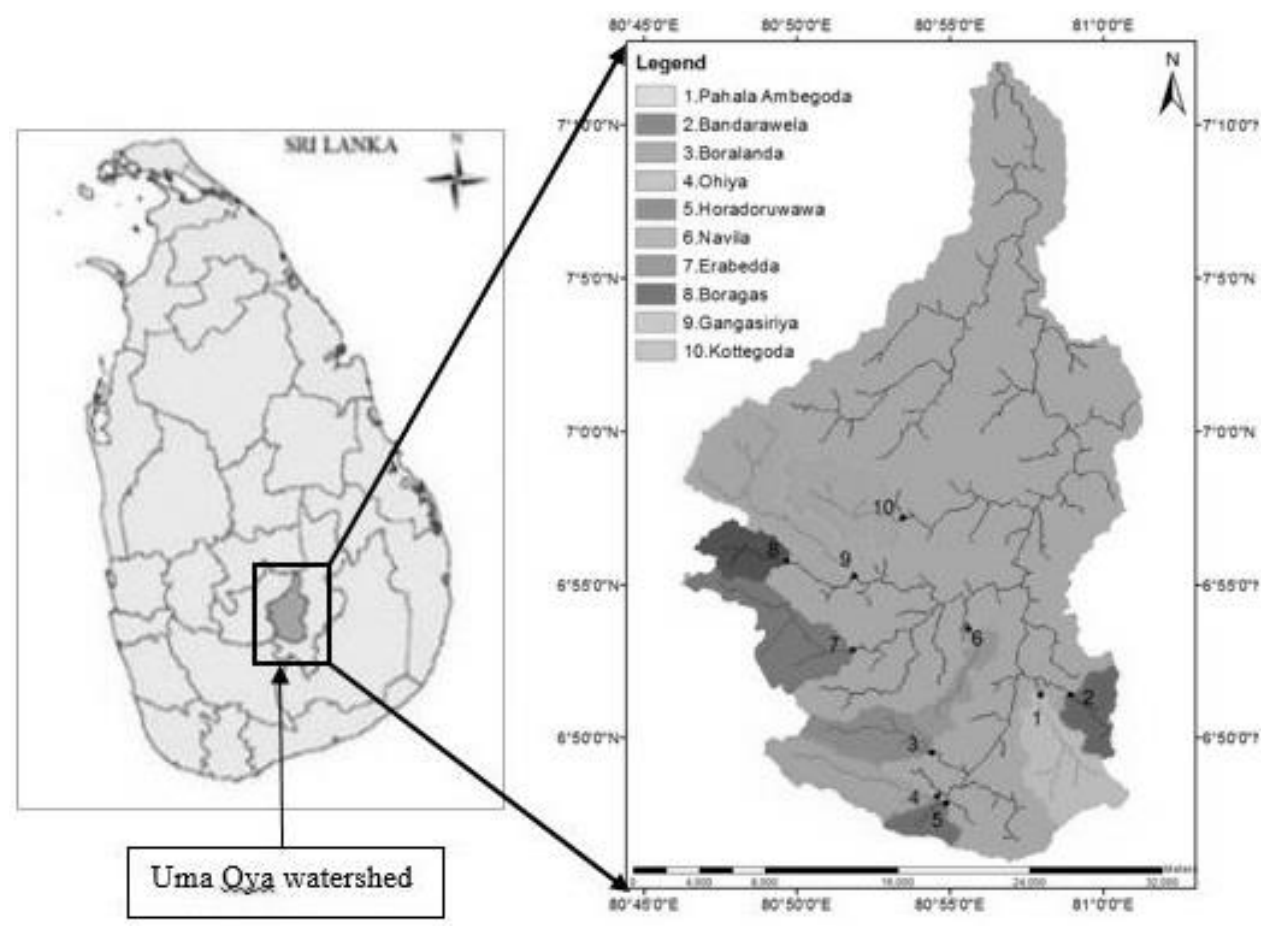

Figure 1: Map of study area

\section{Soil erosion assessment with InVEST SDR model}

The InVEST SDR model (version 3.3.2) was used to map and assess the soil erosion in the UOW. The InVEST has developed as a part of the Natural Capital Project, an association comprised of the Stanford University, the Nature Conservancy and the World Wildlife Fund and works with various other institutions. The InVEST is a toolset of models which quantifies and maps the values of eco systems services basically under the categories of terrestrial, fresh water and marine systems in order to establish a clear understanding of nature's values, required in the decision-making process. The InVEST SDR model can be used to map over land sediment generation and delivery to the stream (Nelson et al. 2009).

\section{Data sources and preparation}

The SDR model requires seven types of data inputs (Table 1) for the estimation of soil erosion. All the raster and vector input variables were prepared by using ArcMap TM 10.4. 
Table 1: Input data for the InVEST SDR model and sources

\begin{tabular}{|c|c|c|}
\hline No. & Input data & Sources \\
\hline 1 & Digital Elevation Model (DEM) & SRTM Satellite images (2014) \\
\hline 2 & $\begin{array}{l}\text { Rainfall Erosivity Index }(\mathrm{R} \\
\text { factor })\end{array}$ & $\begin{array}{l}\text { Roose equation was used with rainfall data from } \\
20 \text { rainfall gauging stations in study area }\end{array}$ \\
\hline 3 & Soil Erodibility (K factor) & Department of Irrigation, Sri Lanka \\
\hline 4 & Land Use Land Cover (LULC) & Department of Survey, Sri Lanka \\
\hline 5 & Watersheds & $\begin{array}{l}\text { Demarcation based on Hydrology tool in the } \\
\text { ArcMap }^{\mathrm{TM}} 10.4\end{array}$ \\
\hline 6 & Biophysical Table & From existing data ( $\mathrm{C}$ and $\mathrm{P}$ factors) \\
\hline 7 & Threshold Flow Accumulation & From available global data \\
\hline
\end{tabular}

Digital Elevation Model: The DEM is a raster dataset and it consists of an elevation value for each cell of it. The DEM for the Uma Oya Watershed was prepared using Shuttle Radar Topography Mission (SRTM) satellite images with $30 \mathrm{~m} \times 30 \mathrm{~m}$ resolution. The DEM was filled to remove the sinks by using ArcMap ${ }^{\mathrm{TM}} 10.4$.

Rainfall Erosivity Index $(R)$ : $\mathrm{R}$ is a raster data set with an index value of erosivity for each cell. Annual rainfall data of 20 rainfall gauging stations in the study area were collected from the Department of Meteorology, Sri Lanka. Then the rainfall erosivity index was calculated using Roose equation (Roose, 1996):

$R=a \times$ Precipitation

Eq. (1)

Where, $\mathrm{a}=$ constant or 0.3 (standard in tropical mountain areas),

Precipitation $=$ annual precipitation in millimetres $(\mathrm{mm})$

Soil erodibility $(K)$ : $\mathrm{K}$ is a raster data set with a soil erodibility value for each cell. The digital data on soil erodibility for the UOW area were obtained from the Department of Irrigation Sri Lanka. Erodibity values used to generate the soil erodibity map for the UOW are based on two major soil types (Table 2).

Land Use Land Cover (LULC): LULC (Figure 2) is also a raster data set with an integer LULC code for each cell. The digital data on LULC for the UOW area were obtained from the Survey Department of Sri Lanka. Specific codes were assigned for each type of the LULC, corresponding to the data used in the biophysical table. 
Table 2: Soil erodibility values ( $K$ factor)

\begin{tabular}{lc}
\hline Soil Type & K \\
\hline Reddish brown earth & 0.27 \\
Red-yellow podzolic soils & 0.22 \\
\hline
\end{tabular}

Source: (Weerasinghe et al. 2016)

Watersheds: Watersheds are delineated as shape files of polygons using ArcMap ${ }^{\mathrm{TM}}$ 10.4 .

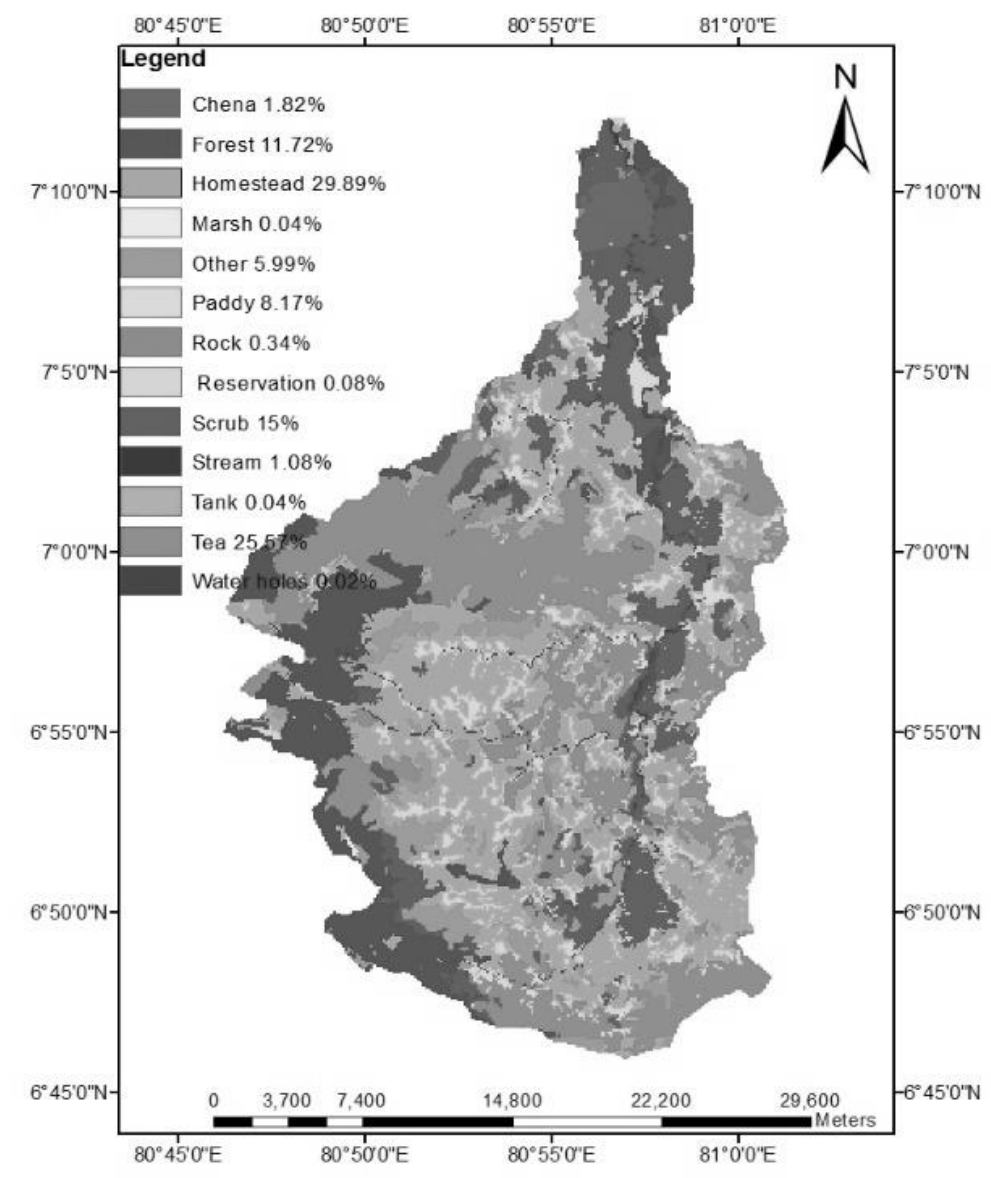

Figure 2: Land Use Land Cover map 
Biophysical table: Biophysical table is a .csv table which included the model information corresponding to each of the land use classes. Biophysical table (Table 3 ) was prepared using the information on crop management factor ( $\mathrm{C}$ factor), practice management factor ( $\mathrm{P}$ factor) and sediment retention value.

Table 3: Biophysical table

\begin{tabular}{clccc}
\hline LU Code & LULC Description & C factor & P factor & Sediment retention \\
\hline 1 & Forest & 0.001 & 0.1 & 0.95 \\
2 & Scrub land & 0.7 & 0.1 & 0.8 \\
3 & Marsh & 0.001 & 0.1 & 0.8 \\
4 & Rock & 0.001 & 0.1 & 0.05 \\
5 & Stream area & 0.001 & 0.001 & 0.05 \\
6 & Water holes area & 0.001 & 0.001 & 0.05 \\
7 & Tank area & 0.001 & 0.001 & 0.05 \\
8 & Reservation & 0.001 & 0.1 & 0.95 \\
9 & Paddy & 0.2 & 0.15 & 0.4 \\
10 & Tea & 0.2 & 0.5 & 0.4 \\
11 & Chena & 0.1 & 0.25 & 0.25 \\
12 & Other cultivation & 0.1 & 0.25 & 0.25 \\
13 & Homesteads & 0.05 & 0.25 & 0.05 \\
\hline
\end{tabular}

Source: (Udayakumara and Gunawardena 2016; Weerasinghe et al. 2016)

Threshold flow accumulation: Threshold directly affects the hydrologic connectivity experience and sediment export. The value is defined as the number of upstream cells that must flow into a cell before it is considered as a part of a stream. By considering the stream network of the study area, three hundred was determined as the value for the threshold flow accumulation.

\section{Results and Discussion}

\section{Soil erosion assessment}

According to the prepared DEM of the UOW the elevation of the study area varies from $155 \mathrm{~m}$ to $2459 \mathrm{~m}$. The calculated rainfall erosivity index of the study area ranges from 468 to 915 and the soil erodibility values vary from 0.22 to 0.27 . The UOW can be categorized into 13 LULC classes (Figure 2). 


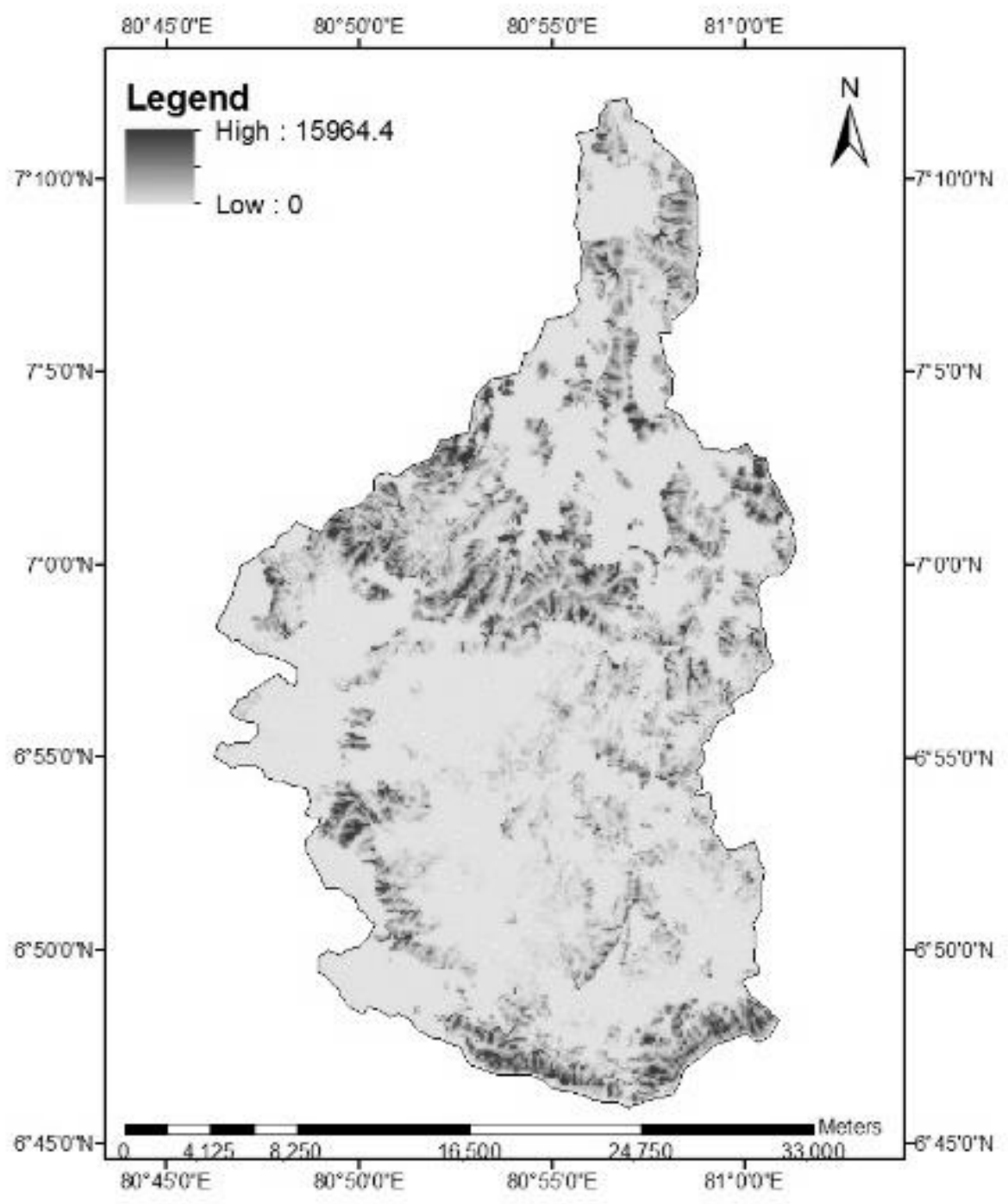

\section{Figure 3: Total soil loss map}

The results of the model are given under 3 major categories. According to that, it provides maps and values for the total soil loss (Figure 3), sediment retention and sediment export (Error! Not a valid bookmark self-reference.). 
Table 4: Resulted values for sediment retention, sediment export and total soil loss

\begin{tabular}{ccccc}
\hline $\begin{array}{c}\text { Watershed } \\
\text { ID }\end{array}$ & $\begin{array}{c}\text { Area } \\
\text { (ha) })\end{array}$ & $\begin{array}{c}\text { Sediment retention } \\
(\mathbf{t} / \mathbf{h a} / \mathbf{y r})\end{array}$ & $\begin{array}{c}\text { Sediment export } \\
(\mathbf{t} / \mathbf{h a} / \mathbf{y r})\end{array}$ & $\begin{array}{c}\text { Total soil loss } \\
(\mathbf{t} / \mathbf{h a} / \mathbf{y r})\end{array}$ \\
\hline 1 & 2743.2 & 700.9 & 13.5 & 252.2 \\
2 & 1269.8 & 61.3 & 0.1 & 34.9 \\
3 & 1423.3 & 856.1 & 15.9 & 115.9 \\
4 & 2333.9 & 1529.9 & 7.2 & 128.5 \\
5 & 691.3 & 1343.8 & 67.2 & 648.6 \\
6 & 1034.8 & 143.1 & 1.5 & 64.9 \\
7 & 2886.8 & 1002.6 & 17.7 & 197.9 \\
8 & 1292.2 & 422.8 & 0.8 & 13.9 \\
9 & 4493.2 & 957.0 & 7.0 & 100.2 \\
\hline 10 & 2401.1 & 1154.4 & 3.9 & 54.1 \\
\hline Watershed & 73120.5 & 889.9 & 14.3 & 182.0 \\
\hline
\end{tabular}

Total soil loss is the total amount (tons) of potential soil loss from a considered land area per sub-watershed. Sediment retention is the amount (tons) of sediment retained by the landscape in a considered land cover per sub-watershed. Sediment export is the amount (tons) of sediment exported to the stream from a considered land cover per sub-watershed.

The natural rates of sediment generation in the UMC have been determined from cosmogenic nuclides as 0.13 to $0.30 \mathrm{t} / \mathrm{ha} / \mathrm{yr}$. (Diyabalanage et al. 2017). According to the results of the model output, soil erosion rate of the sub-watersheds varied between 14.0-648.6 t/ha/yr. The current soil erosion rate of the ten selected subwatersheds of UOW is about 3 to 130 times higher than the soil loss tolerance in Sri Lanka (5 t/ha/yr).

Tea cultivation is one of the major causative reasons behind the intense soil erosion. Based on the LULC map (Figure 3) of the UOW, the percentage of tea crop of the watershed area is $25.6 \%$. 
The sub-watershed of Horadoruwawa (5) has been reported as the highest soil erosion $(648.6 \mathrm{t} / \mathrm{ha} / \mathrm{yr})$ area. The possible reason behind this may be the man-made disturbances which include road construction work and tea cultivation covering a large part of the upper catchment area of the stream. Boragas (8), where upper catchment area is mostly covered with the natural forest cover and the lower catchment region with the properly-managed tea plantations is reported to be the lowest soil erosion sub-watershed (14 t/ha/yr).

Ohiya sub-watershed (4), where surrounding catchment area is under the cover of undisturbed natural forest cover, has been reported as the highest sediment retention area (1530 t/ha/yr). The sub-watershed, Bandarawela (2), is ranked as the lowest sediment retention $(61.3 \mathrm{t} / \mathrm{ha} / \mathrm{yr})$ location in comparison with the other areas of the territory. In relation to the other sites, it is the most urbanized section.

While the highest volume of sediment export $(67.2 \mathrm{t} / \mathrm{ha} / \mathrm{yr})$ has occurred at the Horadoruwawa sub-watershed (5), the lowest volumes of $0.1 \mathrm{t} / \mathrm{ha} / \mathrm{yr}$ and $0.8 \mathrm{t} / \mathrm{ha} / \mathrm{yr}$ have been reported from Bandarwela (2) and Boragas (8) respectively.

The results of the InVEST SDR model gives the statistical values for each resulted map and those values are indicated in the Table 5. 
Table 5: Statistics of pixel based maps of sub-watersheds and total watershed of UOW

\begin{tabular}{|l|c|c|c|c|c|c|c|c|}
\hline \multirow{2}{*}{\multicolumn{1}{c|}{ Map }} & \multicolumn{4}{|c|}{ Sub-watersheds } & \multicolumn{4}{c|}{ Total watershed } \\
\cline { 2 - 10 } & Min & Max & Mean & Std dev. & Min & Max & Mean & Std dev. \\
\hline Soil loss (USLE) & 0.0 & 9633.0 & 121.5 & 358.6 & 0.0 & 15964.4 & 156.8 & 398.4 \\
\hline Soil loss (RKLS) & 0.0 & 219981.7 & 3965.7 & 6817.4 & 0.0 & 219981.7 & 3946.9 & 6225.9 \\
\hline Sediment Retention & 0.0 & 88400.3 & 853.2 & 1796.5 & 0.0 & 87203.9 & 786.2 & 1542.6 \\
\hline Sediment Export & 0.0 & 1098.8 & 10.1 & 37.2 & 0.0 & 3518.3 & 12.7 & 49.1 \\
\hline
\end{tabular}




\section{Conclusions}

The results of the soil erosion assessment revealed that the soil loss of the selected ten sub-watersheds of the UOW ranged from $14-648.5 \mathrm{t} / \mathrm{ha} / \mathrm{yr}$. This current rate of soil loss is 3-130 times higher than the soil loss tolerance in Sri Lanka ( $5 \mathrm{t} / \mathrm{ha} / \mathrm{yr}$ ). The current soil erosion rate is $10-30$ times higher than the soil loss rates calculated in 2003. Human induced land use practices may be the reason for the increasing soil erosion rates of the study area. Sediments delivery into the stream causes negative impacts on the quality of the watershed and it is controlled by the riparian vegetation of the surrounding area of the sub-watersheds. However, findings of the study can be applied to implementation of sustainable watershed management options which are crucial in order to reduce soil erosion and to enhance the quality of the watershed.

\section{References}

Alam K, Rolfe J, Donaghy P (2006) Economic and social impact assessment of water quality improvement. Australasian Journal of Regional Studies, 12(1), 85-102.

AL-Kaisi M, Mark H, Mark AL (2009) Resource Conservation Practices: Soil Erosion and Water Quality. Agriculture and Natural Resources.155

Al-Wadaey, Ziadat F. (2014). A participatory GIS approach to identify critical land degradation areas and prioritize soil conservation for mountainous olive groves - case study. Journal of Mountain Science, 11, 782-791

Cheng X, Liding C, Ranhao S, Kong P (2017) Land use changes and socio-economic development strongly deteriorate river ecosystem health in one of the largest basins in China. Science of the Total Environment 616, 376-385.

Diyabalanage S, Samarakoon KK, Adikari SB, Hewawasam T (2017) Impact of soil and water conservation measures on soil erosion rate and sediment yields in a tropical watershed in the Central Highlands of Sri Lanka. Applied Geography, 79, 103-114.

Gunatilake H, Vieth G (2000) Estimation of on-site cost of soil erosion: A comparison of replacement and productivity change methods. Journal of Soil and Water Conservation. 55, 197-204.

Hewawasam T (2010). Effect of land use in the upper Mahaweli catchment area on erosion, landslides and siltation in hydropower reservoirs of Sri Lanka. J. Natn.Sci.Foundation Sri Lanka, 38, 3-14.

Hewavisenthi ACDS (1997). Management of the Mahaweli, a river in Sri Lanka. Water International, 22(No. 2), 98e107. 
Illangasinghe S, Hewawasam T (2015). Introducing surface sampling threshold factor for suspended sediment transport: Model development using Sri Lankan tropical highland river basins. Hydrology Research, 6(No. 1), 136e155.

Issaka S, Ashraf MA (2017) Impact of soil erosion and degradation on water quality: a review, Geology, Ecology, and Landscapes, 1:1, 1-11

Jayawardana JMCK, Gunawardana WDTM, Udayakumara EPN, Westbrooke M (2016) Land use impacts on river health of Uma Oya, Sri Lanka: implications of spatial scales. Environ Monit Assess, 189:192.

Lal R (2003). Soil erosion and the global carbon budget. Environment International, 29, 437-450.

Mengistie, B. T., Arthur, P. J., 2015. Pesticide use practices among smallholder vegetable farmers in Ethiopian Central Rift Valley. Sprigerlink, 19, 301-3

Nelson E, Ennaanay D, Wolny S, Olwero N, Vigerstol K (2005) InVEST tip User's guid 3.3.2. 1-323.

Panabokke C (1996). Soils and agro-ecological environments of Sri Lanka. In Natural resources series 2 (p. 220). Colombo: Energy and Science Authority.

Pimentel D (1993) World soil erosion and conservation. Cambridge University Press ambridge.

Rathnayake U (2016) Uma Oya multi-purpose development project, Sri Lanka; flood management and social impacts. Research gate, 44-47.

Shi ZH, Fang NF, Wu FZ, Wang L, Yue BJ, Wu GL (2012) Soil erosion processes and sediment sorting associated with transport mechanisms on steep slopes. Journal of Hydrology, 454-455, 123-130

Singh G, Babu R, Narain P, Bhushan LS, Abrol IP (1992) Soil erosion rates in India. Journal of Soil Water Conservation 47: 93-95.

Udayakumara EPN, Gunawardena UADP (2016) Reducing Siltation and Increasing Hydropower Generation from the Rantambe Reservoir, Sri Lanka. SANDEE, $1-20$.

Venkateswarlu J (1994) Managing extreme stresses in arid zone of western Rajisthan, India. In stressed Eco system and Sustainable Agriculture, Varmani SM, Katyal JC, Eswaran H, Abrol IP (eds). Oxford \& IBH Publishing: New Delhi; 161-171

Weerasinghe RNN, Jayawardana JMCK, Udayakumara EPN (2016) Quantitative assessment of soil erosion and its association with river health in Uma Oya watershed in Sri Lanka. ISAE 2016. pp137-140 